\title{
Asexual Spore Release from Saprolegniaceous Water Moulds: Involvement of Calmodulin
}

\author{
By K. SURYANARAYANA† AND D. DES S. THOMAS* \\ Department of Biology, University of Windsor, Windsor, ON N9B 3P4, Canada
}

(Received 26 September 1985)

\begin{abstract}
The localized cell wall lysis associated with asexual spore release from sporangia and spore cysts of saprolegniaceous water moulds appears, based on immunocytochemical and inhibitor studies, to be dependent on calmodulin ( $\mathrm{CaM}$ ). Distinct bands of $\mathrm{CaM}$ surround the exit pores of sporangia and cysts produced by Achlya ambisexualis, Dictyuchus monosporus and Saprolegnia ferax. In differentiating sporangia and cysts, $\mathrm{CaM}$ becomes concentrated in the apical papillae, at the tips of which exit pores are formed. While all stages of sporulation can be inhibited to an extent by micromolar concentrations of trifluoperazine, an anti-CaM drug, spore release is the most sensitive.
\end{abstract}

\section{INTRODUCTION}

The mycelium of saprolegniaceous water moulds consists of coenocytic filamentous hyphae. Differentiation of vegetative tips into asexual sporangia is induced by starvation in the presence of calcium (Griffin, 1966). During sporangiogenesis, protoplasm streams towards the hyphal tip and a septum forms delimiting the terminal sporangium. Cytoplasmic cleavage in the sporangium yields uninucleate spores. The hyphal tip, which is pointed during vegetative growth, becomes rounded (Fig. $1 a$ ) and develops a papilla (Fig. $1 b$ ), at the apex of which an exit pore is formed (Fig. 1c). The patterns of asexual spore production and release are important taxonomic criteria in the family Saprolegniaceae (Johnson, 1956). In Achlya, the spores usually emerge and encyst at the mouth of the sporangium (Fig. $1 d$; achlyoid-type). A cyst can germinate directly (aplanetically) by producing a germ tube which develops into a new mycelium, or it may serve as a zoosporangium, releasing a single zoospore through an exit pore. In Saprolegnia, the zoospores swim away from the sporangium before encysting. The spores of Dictyuchus encyst within the sporangium, and zoospores are released through exit pores formed in each cyst. Spores of $A$ chlya sometimes encyst within the sporangium and zoospores emerge as in Dictyuchus (dictyuchoid pattern).

Calmodulin $(\mathrm{CaM})$ is a multifunctional $\mathrm{Ca}^{2+}$-binding protein found in eukaryotes. Discovered as an activator of cyclic nucleotide phosphodiesterase, $\mathrm{CaM}$ has since been shown to activate numerous enzymes in a $\mathrm{Ca}^{2+}$-dependent manner and has been implicated in the regulation of several physiological processes, including actin and tubulin polymerization, secretion and the activation of membrane-bound ion pumps (Wang \& Waisman, 1979; Klee et al., 1980; Means \& Dedman, 1980; Klee \& Vanaman, 1982; Steinhardt \& Alderton, 1982). Phenothiazine antipsychotic drugs such as trifluoperazine (TFP) inhibit the activity of CaM and have been used to probe its functions (Speaker et al., 1980; Roufogalis, 1982; Weiss et al., 1982). Recently, we described the purification and characterization of CaM from the water mould Achlya ambisexualis (Suryanarayana et al., 1985). In Achlya, the $\mathrm{Ca}^{2+}$-dependent induction of asexual sporulation is associated with a doubling of the $\mathrm{CaM}$ level in non-induced

† Present address: Department of Medicine, University of Alberta, Edmonton, Alberta T6G 2G3, Canada.

Abbreviations: CaM, calmodulin; TFP, trifluoperazine. 
mycelia. Here we show evidence for the possible involvement of $\mathrm{CaM}$ in the localized lysis of sporangia and spore cysts which precedes spore release from the water moulds Achlya ambisexualis, Dictyuchus monosporus and Saprolegnia ferax.

\section{METHODS}

Growth and sporangial induction. A. ambisexualis Raper (male strain, E87), D. monosporus and S. ferax were grown from a spore inoculum in peptone/yeast extract/glucose medium (Cantino \& Lovett, 1960). The cultures were incubated at room temperature $\left(22-25^{\circ} \mathrm{C}\right)$ with gentle agitation on a reciprocating shaker for $24-36 \mathrm{~h}$. When the cultures reached the mid-exponential phase of growth, the mycelia were rinsed with and suspended in $5 \times 10^{-4} \mathrm{M}-\mathrm{CaCl}_{2}$ (induction medium) to induce sporulation (Griffin, 1966). Under these conditions, sporulation took 4-6 h. Mycelia at various stages of induction were harvested and used for immunofluorescence and inhibitor studies.

Indirect immunofluorescence localization of CaM. For indirect immunofluorescence (Suryanarayana, 1985), colonies were harvested by centrifugation or by filtration on a Nalgene Millipore filter ( $45 \mu \mathrm{m}$ pore size), washed in $50 \mathrm{~mm}$-sodium phosphate buffer $(\mathrm{pH} 6.5)$ and fixed in $3.7 \%(\mathrm{v} / \mathrm{v})$ formaldehyde in sodium phosphate buffer for $90 \mathrm{~min}$; rinsed in sodium phosphate buffer with $2-3$ changes $(30 \mathrm{~min})$ and in $0.4 \mathrm{M}$-mannitol $(\mathrm{pH} 5.5)$; treated with $2 \%(\mathrm{w} / \mathrm{v})$ Cellulysin in $0.4 \mathrm{M}$-mannitol $(30-40 \mathrm{~min})$ to permeabilize the hyphal walls (Wick et al., 1981; Kilmartin \& Adams, 1984) and washed in phosphate-buffered saline (PBS) for $30 \mathrm{~min}$. PBS was prepared as two stock solutions, each in $500 \mathrm{ml}$, which were combined and adjusted to $\mathrm{pH} 7.4$ (Welsh, 1983). After washing, the specimens were fixed on to $0.1 \%$ poly-L-lysine-coated slides, permeabilized for 15-20 min in cold methanol $\left(-20^{\circ} \mathrm{C}\right.$ ) and rehydrated with PBS/BSA (PBS with $1 \%$ bovine serum albumin). Permeabilized cells were then treated with primary antibodies to rat testis calmodulin (diluted 1:100 in PBS) for $90 \mathrm{~min}$ at $37^{\circ} \mathrm{C}$ in a moist chamber, rinsed $(3 \times 10 \mathrm{~min})$ in PBS/BSA and stained with rhodamine-conjugated second antibody as above. After a wash in PBS/BSA and a rinse in distilled water, the preparations were mounted in a drop of mounting medium ( $9: 1, \mathrm{v} / \mathrm{v}$, glycerol/PBS containing $0 \cdot 1 \% p$-phenylenediamine). The excess mounting medium was blotted away from the edge of the cover slip with a filter paper and the edges were sealed with paraffin wax.

Immunofluorescence control tests were done to determine the specificity of localization. They included incubation with (i) second antibody alone, (ii) pre-immune serum instead of the primary antibody and (iii) primary antibody pre-absorbed with a 10 -fold excess of $\mathrm{CaM}$. In certain controls, the Cellulysin treatment was omitted.

The preparations were examined with a Leitz Orthoplan photomicroscope equipped with a Ploem epifluorescence attachment, fluorescein and rhodamine filters and Fluotar objectives. Images were recorded on Ilford HP5 or Kodak Tri-X pan (ASA 400) black and white films and developed at 1600 ASA. Excellent colour transparencies were obtained using Kodak Ektachrome P800/1600 colour reversal professional film pushprocessed to 1600 ASA.

Inhibitor studies. Experiments with the anti-CaM drug TFP were of three types. (a) TFP at 1, 2, 5, 10, 25, 50 and $100 \mu \mathrm{M}$ was added from the start of induction of asexual sporulation, and the stages of sporangiogenesis observed after $6 \mathrm{~h}$ were recorded. Reversibility of TFP inhibition was determined after a wash and subsequent incubation in induction medium. (b) Colonies were pre-induced for $3 \mathrm{~h}$ at which time aggregation and septation were complete in about $90 \%$ of hyphal tips. TFP was then added to $50 \mathrm{ml}$ suspensions of colonies in $125 \mathrm{ml}$ Erlenmeyer flasks. Induction was continued with agitation for $3 \mathrm{~h}$. For reversibility studies, TFP-treated mycelia were washed after $3 \mathrm{~h}$ and transferred to fresh induction medium. Spore release was monitored microscopically at various intervals. (c) Fresh cysts were incubated in Petri dishes with different concentrations of TFP at room temperature. After $2 \mathrm{~h}$, TFP in reversibility treatments was removed by washing and replacing by fresh induction medium and zoospore release was monitored. All inhibitor experiments were repeated at least twice.

Chemicals. Rat testis anti-calmodulin was a gift from Dr R. L. Pardue, Division of Endocrinology, University of Texas Medical School, Houston, Tx., USA. Some supplies were obtained as follows: rhodamine-conjugated second antibody (New England Nuclear), Cellulysin (Calbiochem) and TFP (Boehringer-Mannheim). Other supplies were from Sigma.

\section{RESULTS AND DISCUSSION}

$\mathrm{CaM}$-associated fluorescence in a pre-sporangial hypha of $A$. ambisexualis was concentrated in the apical zone (Fig. $1 e$ ). Papillate sporangia showed a zone of low fluorescence between the bright apical papilla and the remainder of the sporangium (Fig. $1 f$ ). After sporangia had released their spores, CaM persisted as a collar surrounding the exit pore (Fig. $1 \mathrm{~g}$ ). Smaller collars were observed around the exit pores of achlyoid cysts (Fig. $1 \mathrm{~g}$ ) and cysts in the sporangium of $D$. monosporus (Fig. $1 h$ ). The distribution of CaM in $S$. ferax was similar to that in A. ambisexualis (not shown). 

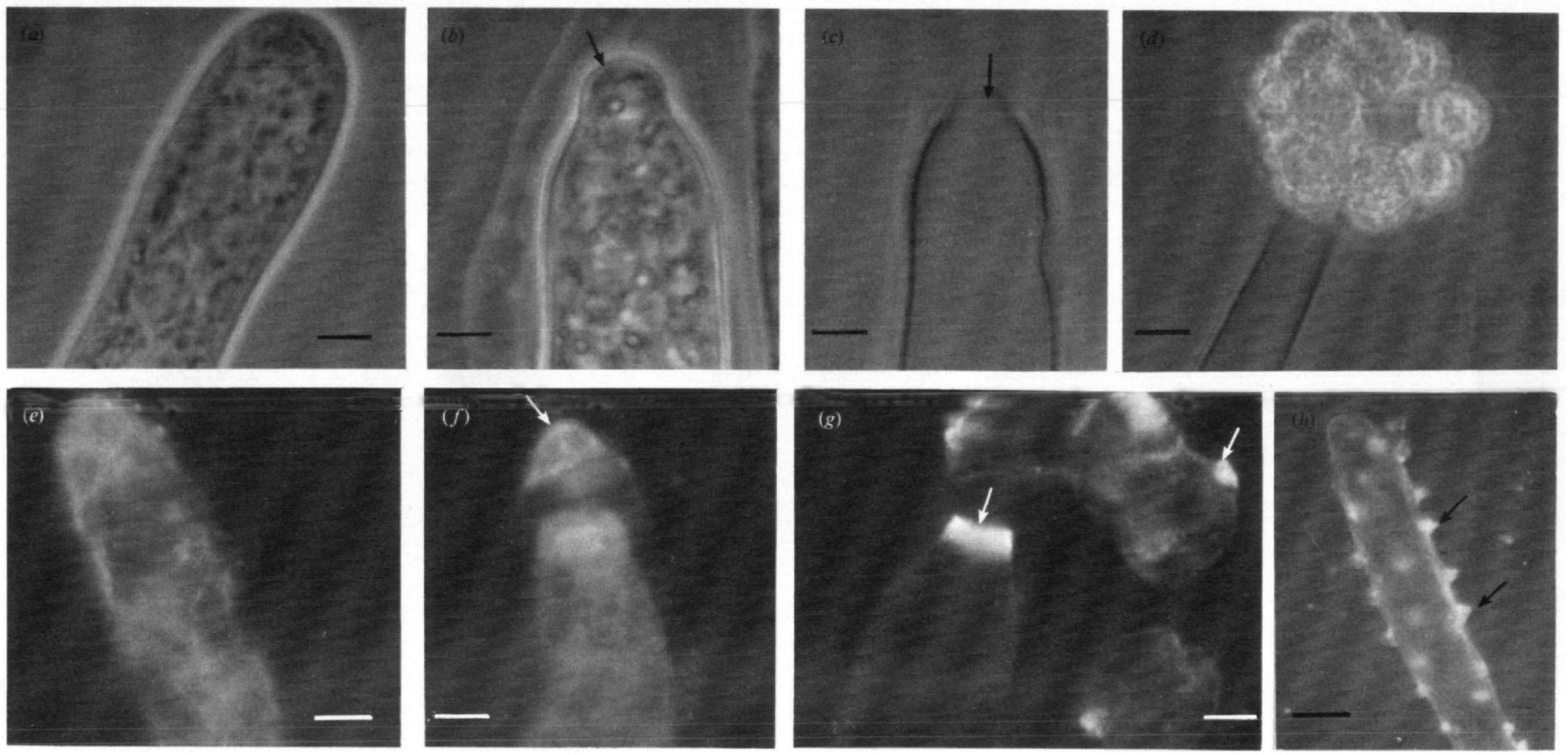

Fig. 1. Stages of sporangial morphogenesis observed in $A$. ambisexualis $(a-g)$ and $D$. monosporus $(h)$ by phase contrast microscopy $(a-d)$ and by immunofluorescence $(e-h)$ after staining for calmodulin (CaM). Hyphal tips, initially pointed, become rounded $(a)$ after the start of induction. The sporangium develops an apical papilla $(b$, arrowed), the tip of which develops an exit pore ( $c$, arrowed) which becomes visible after spore release. The spores exit through the pore and immediately encyst forming a typical achlyoid cyst mass $(d)$ at the mouth of the sporangium. CaM fluorescence in a differentiating hyphal tip $(e)$ is diffuse with apical concentration. Strong $\mathrm{CaM}$ fluorescence is localized in the apical papilla ( $f$, arrowed). In empty sporangia and cysts ( $g$, arrowed) $\mathrm{CaM}$ is concentrated in bands around sporangial and cyst exit pores. In $D$. monosporus where spores encyst within the sporangium, exit pores of individual cysts show bands of CaM $(h$, arrowed). Bars, $5 \mu \mathrm{m}$ except in (e) $(50 \mu \mathrm{m})$ and $(h)(20 \mu \mathrm{m})$. 


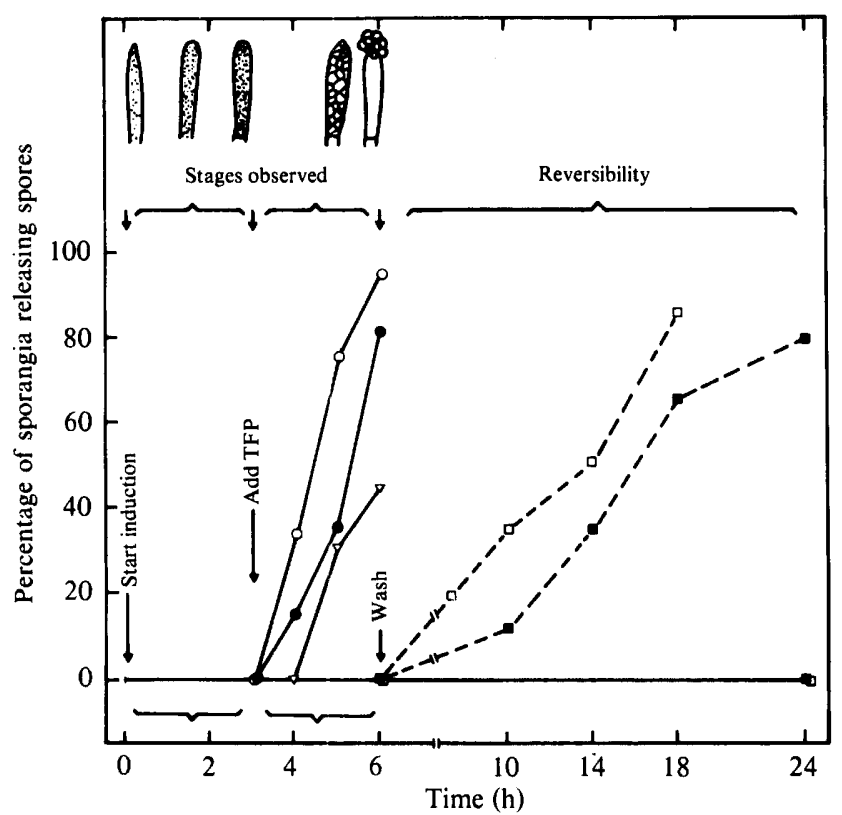

Fig. 2. TFP inhibition of spore release in A. ambisexualis. TFP was $1(\odot), 10(\nabla), 20(\square)$ or $50(\square) \mu \mathrm{M}$, in $5 \times 10^{-4} \mathrm{M}-\mathrm{CaCl}_{2} ; \mathrm{O}$, control. The dashed lines show recovery in $\mathrm{CaCl}_{2}$ after a wash. The morphological stages observed during sporangial induction are, from left to right, vegetative tip, rounded tip during cytoplasmic aggregation, young sporangium with septum, cleaving sporangium with papillate tip and empty sporangium with cysts. The results are of a typical experiment.

TFP reversibly inhibits sporangiogenesis and spore release in Achlya. Applied from the start of induction, $10 \mu \mathrm{M}$-TFP was the lowest concentration that completely inhibited differentiation of sporangia, while $1 \mu \mathrm{M}$-TFP inhibited only spore release (not shown). When applied $3 \mathrm{~h}$ after the start of induction (Fig. 2), concentrations exceeding $10 \mu \mathrm{M}$ completely and reversibly inhibited spore release without detectable effects on apical papilla formation. Zoospore release from cysts was $86 \%$ in controls, $32 \%$ at $10 \mu \mathrm{M}$-TFP and $0 \%$ at higher concentrations. Although sensitivity of a process to $\mathrm{CaM}$ inhibitors such as TFP does not prove involvement of $\mathrm{CaM}$, it is consistent with a CaM-dependent process (Speaker et al., 1980; Roufogalis, 1982; Weiss et al., 1982). While all stages of sporulation could be inhibited to an extent by micromolar concentrations of TFP, spore release was particularly sensitive.

The formation of exit pores in sporangia and cysts of saprolegniaceous water moulds usually involves localized hydrolysis of wall material (Gay \& Greenwood, 1966; Heath, 1976). In Achlya, a fungus with cellulosic walls (Parker et al., 1963), the formation of hyphal branches, which is preceded by localized accumulation of vesicles (Mullins \& Ellis, 1974), has been correlated with elevated levels of mycelial and secreted cellulase (Thomas \& Mullins, 1967). This enzyme has been localized cytochemically in dictyosomes and vesicles of $A$. ambisexualis and Saprolegnia monoica and in association with the cell wall (Nolan \& Bal, 1974; Fèvre, 1979). Developing sporangia of members of the Saprolegniaceae show an accumulation of vesicles in the exit papillae (Heath et al., 1971; Armbruster, 1980). Experiments using cycloheximide as a protein synthesis inhibitor suggest that either a wall hydrolase or an activator of such an enzyme may be a final product of protein synthesis in the sporangium of $A$. ambisexualis (Timberlake $e \dot{t}$ al., 1973). Immunochemical localization of antigens in fungi and plants requires prior wall hydrolysis to allow penetration of the antibodies (Wick et al., 1981; Hoch \& Staples, 1983). Comparison of $\mathrm{CaM}$ localization with and without prior exposure of the cell walls to hydrolysis by Cellulysin suggests that the sporangial walls become permeable to macromolecules in the region of the apical papilla. In treatments omitting enzymic hydrolysis, vegetative hyphae and young sporangia were unstained, while empty sporangia showed $\mathrm{CaM}$ fluorescence surrounding 
the exit pores. Mature sporangia which had not released their spores were stained only in the apical papillae, indicating localized modification of wall permeability associated with the future exit pore. CaM has been implicated in numerous secretory systems (Steinhardt \& Alderton, 1982), including cellulase secretion by Trichoderma reesii (Hill \& Waggener, 1984). Evidence for a cytoskeletal-regulatory role of $\mathrm{CaM}$ is emerging (Schleicher et al., 1982; Kakiuchi \& Sobue, 1983). Whether CaM may be implicated in the pattern of electrical current observed at the apex of the Achlya sporangium (Armbruster \& Weisenseel, 1983) remains to be determined. The persistence of $\mathrm{CaM}$ in the collars of evacuated sporangia, where electron micrographic study indicates the loss of the original plasma membrane (Gay \& Greenwood, 1966), suggests that CaM may be secreted into the sporangial wall, perhaps in association with wall-hydrolysing enzymes.

Note added in proof. Since this report was submitted, the following paper on CaM localization in plant cells, including Achlya, has been brought to our attention: Hausser, I., Herth, W. \& Reiss, H. D. (1984). Calmodulin in tip-growing plant cells, visualized by fluorescing calmodulinbinding phenothiazines. Planta 162, 33-39.

We thank Dr R. L. Purdue for the gift of rat testis anti-calmodulin, Drs W. G. Benedict and R. J. Bayer for the use of the fluorescence microscope, Dr E. K. Manavathu for his suggestions and Mrs Monica Jewell for secretarial assistance. This research was supported by grants from the Natural Sciences and Engineering Research Council of Canada and the Research Board of the University of Windsor.

\section{REFERENCES}

ARMBRUSTER, B. L. (1980). Sporangiogenesis and spore discharge in members of the Saprolegniaceae. $\mathrm{PhD}$ thesis, Duke University, Durham, NC, USA.

ARMBruster, B. L. \& WeISENSEEL, M. H. (1983). Ionic currents traverse growing hyphae and sporangia of the mycelial water mold Achlya debaryana. Protoplasma $115,65-69$.

Cantino, E. C. \& Lovett, J. S. (1960). Respiration of Blastocladiella during bicarbonate-induced morphogenesis in synchronous culture. Physiologia plantarum 13, 450-458.

FÈVRE, M. (1979). Glucanases, glucan synthases and wall growth in Saprolegnia monoica. In Fungal Walls and Hyphal Growth, pp. 256-262. Edited by J. H. Burnett \& A. P. J. Trinci. Cambridge: Cambridge University Press.

Gay, J. L. \& Greenwood, A. D. (1966). Structural aspects of zoospore production in Saprolegnia ferax with particular reference to the cell and vacuolar membranes. In The Fungus Spore, pp. 95-110. Edited by M. F. Madelin. London: Butterworths.

GrIFFIN, D. H. (1966). Effect of electrolytes and differentiation in Achlya sp. Plant Physiology 41, 1254-1256.

HEATH, I. B. (1976). Ultrastructure of fresh water Phycomycetes. In Recent Advances in Aquatic Mycology, pp. 603-650. Edited by E. B. Gareth Jones. New York: John Wiley \& Sons.

Heath, I. B., Gay, J. L. \& Greenwood, A. D. (1971). Cell wall formation in the saprolegniales: cytoplasmic vesicles underlying developing walls. Journal of General Microbiology 65, 225-232.

Hill, T. W. \& Waggener, R. G. (1984). Cellulase secretion by Trichoderma reesii is inhibited by anticalmodulin drugs. Mycological Society of America Newsletter 35(1), p. 28, Abstract.
Hoch, H. C. \& STAPLES, R. C. (1983). Visualization of actin in situ by rhodamine-conjugated phalloin in the fungus Uromyces phaseoli. European Journal of Cell Biology 32, 52-58.

JoHnson, T. W., JR (1956). The Genus Achlya: Morphology and Taxonomy, pp. 1-180. Ann Arbor: University of Michigan Press.

KaKIUCHI, S. \& SobUe, K. (1983). Control of the cytoskeleton by calmodulin and calmodulin-binding proteins. Trends in Biochemical Sciences, February, 59-62.

Kilmartin, J. V. \& Adams, A. E. M. (1984). Structural rearrangements of tubulin and actin during the cell cycle of Saccharomyces. Journal of Cell Biology 98, 922-933.

Klee, C. B. \& Vanaman, T. C. (1982). Calmodulin. Advances in Protein Chemistry 35, 213-303.

Klee, C. B., Crouch, T. H. \& Richman, P. G. (1980). Calmodulin. Annual Review of Biochemistry 49, 489515.

Means, A. R. \& Dedman, J. R. (1980). Calmodulin an intracellular calcium regulator. Nature, London 285, 73-77.

Mullins, J. T. \& Ellis, E. A. (1974). Sexual morphogenesis in Achlya: ultrastructural basis for the hormonal induction of antheridial hyphae. Proceedings of the National Academy of Sciences of the United States of America 71, 1347-1350.

Nolan, R. A. \& BAL, A. K. (1974). Cellulase localization in hyphae of Achlya ambisexualis. Journal of Bacteriology 117, 840-843.

Parker, B. C., Preston, R. D. \& Fogg, G. E. (1963). Studies on the structure and chemical composition of the cell walls of Vaucheriaceae and Saprolegniaceae. Proceedings of The Royal Society 158, 435-445. 
Roufogalis, B. D. (1982). Specificity of trifluoperazine and related phenothiazine for calcium-binding proteins. In Calcium and Cell Function, vol. III, pp. 129-159. Edited by W. Y. Cheung. New York: Academic Press.

SChleicher, M., Iverson, D. B., Van Eldik, L. J. \& Watterson, D. M. (1982). Calmodulin. In The Cytoskeleton in Plant Growth and Development, pp. 85-106. Edited by C. W. Lloyd. New York: Academic Press.

Speaker, M. G., Sturgill, T. W., Orlow, S. J., Chia, G. H., Pif ko-Hirst, S. \& Rosen, O. M. (1980). The effect of trifluoperazine on the macrophage-like cell line, J 774. Annals of the New York Academy of Sciences 356, 162-178.

Steinhardt, R. A. \& Alderton, J. M. (1982). Calmodulin confers calcium sensitivity on secretory exocytosis. Nature, London 295, 154-155.

Suryanarayana, K. (1985). Studies on a calciumdependent activator protein, structurally and functionally homologous to Calmodulin, from the water mold Achlya ambisexualis. PhD thesis, University of Windsor, Windsor, Ontario, Canada.

Suryanarayana, K., Thomas, D. Des S. \& Mutus, B. (1985). Calmodulin from the water mold Achlya ambisexualis: isolation and characterization. In Cell Biology International Reports, vol. 9, pp. 389-400. Edited by L. M. Franks. New York: Academic Press.

Thomas, D. DEs S. \& Mullins, J. T. (1967). Role of enzymatic wall softening in plant morphogenesis: hormonal induction in Achlya. Science 156, 84-85.

Timberlake, W. E., McDowell, L., Cheney, J. \& Griffin, D. H. (1973). Protein synthesis during the differentiation of sporangia in the water mold Achlya. Journal of Bacteriology 116, 67-73.

Wang, J. H. \& WaISMaN, D. M. (1979). Calmodulin and its role in the second-messenger system. Current Topics in Cellular Regulation 15, 47-107.

Weiss, B., Prozialeck, W. C. \& Wallace, T. L. (1982). Interaction of drugs with calmodulin. Biochemical Pharmacology 31, 2217-2226.

WELSH, M. J. (1983). Localization of calmodulin and calmodulin-acceptor sites by fluorescence methods. Methods in Enzymology 102, 110-121.

Wick, S. M., Seagull, R. W., Osborn, M., Weber, K. \& GUNNING, B. E. S. (1981). Immunofluorescence microscopy of organized microtubule arrays in structurally stabilized meristematic plant cells. Journal of Cell Biology 89, 685-690. 